Istanbul Finance Congress, November 1-2, 2018, Istanbul, Turkey.

\title{
ECONOMIC VALUE ADDED and CORPORATE FIRM VALUE IMPLICATIONS
}

\author{
DOI: 10.17261/Pressacademia.2018.985 \\ PAP-IFC- V.8-2018(17)-p.76-79
}

\section{Dilek Teker ${ }^{1}$, Elcin Aykac Alp ${ }^{2}$}

${ }^{1}$ Isik University, Faculty of Business, Sile Campus, Istanbul. Turkey dilek.teker@isikun.edu.tr, ORCID:0000-0002-3893-4015

${ }^{2}$ Istanbul Commerce University, Faculty of Business, Beyoglu, Istanbul. Turkey ealp@ticaret.edu.tr, ORCID: 0000-0001-9076-2102

\section{To cite this document}

Teker, D., Alp, E. A. (2018). Economic value added and corporate firm value implications. PressAcademia Procedia (PAP), V.8(17), p.76-79. Permanent link to this document: http://doi.org/10.17261/Pressacademia.2018.985

Copyright: Published by PressAcademia and limited licenced re-use rights only.

\section{ABSTRACT}

Purpose - Recent studies focus on the corporate firm value and relation with financial parameters. This study reveals the interaction between economic value added on corporate firm value and specific financial parameters such as P/E, WACC, ROE and ROIC. This analysis focuses primarily on how corporate value is effected by the other variables and the duration that this influence leads.

Methodology - The quarterly data is derived for public banks in Turkish markets for the period 2006Q1-2018Q3. In the light of the data obtained, PE, ROE, ROIC, WACC and WACCEVA values calculated for seven public banks. Each financial indicator was analyzed in terms of trend and it was decided that the existing deterministic components should be eliminated in order not to affect the analysis result.

Findings- The summarized results indicate different occasions for each stock such as economic value added has significant effect on firm value for couple of the firms and WACC and EVA variables have one period lagged effect for all stocks.

Conclusion- We indicate that firm value is effected from financial measures and further analysis should focus on investor buy/sell behaviors in time lags.

Keywords: Corporate firm value, unit root tests, VAR models

JEL Codes: M40, M41, G17

\section{INTRODUCTION}

Determinants of stock price is obviously a very trend topic in financial management. There are various tools to measure the pricing effect and the shareholder value creation for corporations. This awareness lead corporations to attract markets within value maximization. There are many studies on corporate values, such as Keasey and Short (1997), Firth (1998), Naceur and Goaied (2002), Brio et al. (2003) Becchetti and Adriani (2004), Naceur and Goaied (2004), Jones and Danbolt (2004), Alonso et al. (2005), and Abhyankar et al. (2005). There are varios studies that examine the relation between firm value and different financial measures. Poker, Murakami and Belli (2015) test whether the economic value added (EVA) was a determinant of the changes in the capital structure in the worldwide steel mill sector during economic crises. Evidence is found to support a significant relationship between the changes in economic value added (EVA) and the changes in debt ratios. Atchyuthan and Vijayakumaran (2017) tested the determinants of firm value as a measure of $P$ /E ratio for manufacturing firms from 2011 to 2015 based on convenient sampling. Empirical results of pooled OLS regression with cluster robust standard error; their evidence state that that price earnings ratio is positively and significantly associated with return on equity and market to book ratio. Further their results show that dividend per share, earnings growth ratio and firm size are not associated with price earnings ratio. Ramcharran (2002) sets economic growth and credit risk as the determinants of the P/E ratio of 21 emerging markets. Annual data for the period 1992-1999 are used with seemingly unrelated regression (SUR) techniques to obtain cross-section and pooled-data estimates. The multivariate results indicate the significance of growth and the univariate results, the significance of both growth and credit risk. This study focuses on the firm value and how this performance is influenced by selected financial parameters.

\section{DATA AND ECONOMETRIC RESULTS}

In this study we employ specific tests to gather an information about the relation between stock price and various financial measures. The database includes Price / Earnings ratio as the stock price proxy. The determinants are modelled as weighted average cost of capital (WACC), Economic value added (EVA), Return on equity (ROE) and Return on Invested Capital (ROIC). The quarterly data is derived for public banks in Turkish markets for the period 2006Q1-2018Q3. Within this analysis, the relationship between the relevant variables is examined and the omitted variable problem is not encountered. In the light of the data obtained, PE, ROE, ROIC, WACC and WACCEVA values calculated for seven public banks. Each financial indicator was analyzed in terms of trend and it was decided that the existing deterministic components should be eliminated in order not to affect the analysis result. Initialy, Hodrick-Prescott filter was applied to remove deterministic components from all variables. All variables except WACC and WACCEVA are obtained as ratios. Thus WACC and 
WACCEVA variables transformed to percentages. In next step Augmented Dickey Fuller (ADF), Phillips - Perron (PP) unit root tests were employed. Given the hypothesis we want to test and the characteristics of the variables we use in the analysis, the VAR models are decided to be appropriate and the analysis is continued with the VAR models. Below are the model results are summarized for each stock. For Akbank stock; first lag for the WACC variable in the VAR model was used by considering that it would affect the model with one period delay. The lag length for VAR models is determined using LR, FPE, AIC, SC, HQ, information criteria. The effect of WACCEVA on this system rather than WACC has also been tested and found insignificant. The obtained relation results on WACC and WACCEVA are also reported and discussed together at the end of this section. Impulse-Response analyses for AKBANK and the impulse of WACC variable are given below for this system. The first graph shows the response of the PE ratio for the effect of a positive shock on WACC variable. As seen from the graph the response on PE ratio turns to positive in the third period and its maximum positive impact can be seen on the fifth period.

Figure 1: Response to Cholesky One S.D. Innovations

Response to Cholesky One S.D. Innovations \pm 2 S.E.

Response of AKPE to AKWACC(-1)

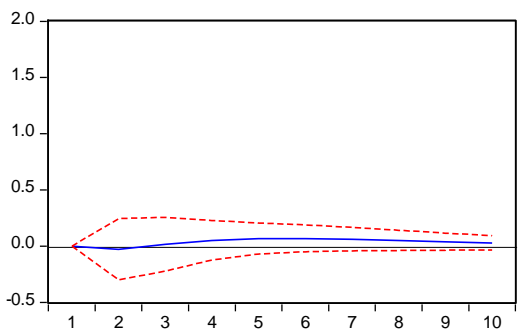

Response of AKROEC to AKWACCC(-1)

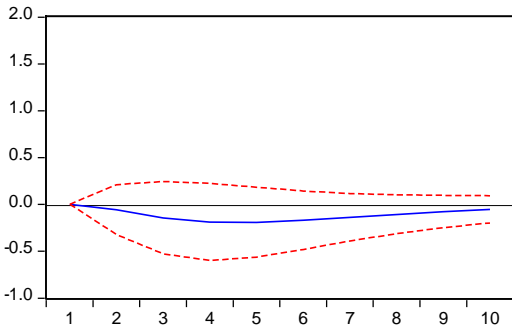

Response of AKROIC to AKWACC (-1)

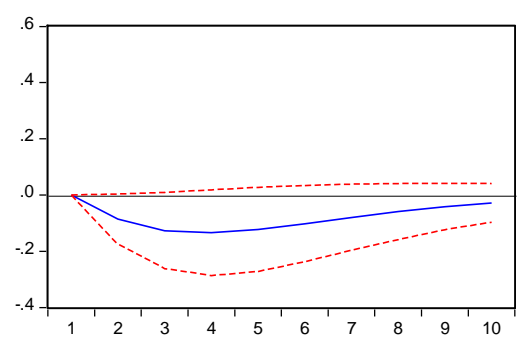

For ISCTR, one lagged VAR model is employed. The first lag for the WACC variable in the VAR model was used by considering that it would affect the model with one period delay as in the previous models. The effect of WACCEVA on this system rather than WACC has also been tested and found insignificant. For the system of ISCTR, a positive shock on WACC leads a weak negative effect on PE ratio. At the end of the eighth term, PE comes to its initial stage. This positive shock on WACC has also negative effect on ROE and ROIC for this system.

Figure 2: Response to Cholesky One S.D. Innovations

Response to Cholesky One S.D. Innovations \pm 2 S.E.

Response of ISCTRPE to ISCTRWACC (-1)

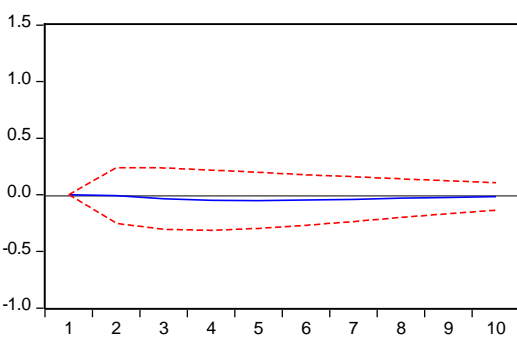

Response of ISCTRROEC toISCTRWACCC(-1)

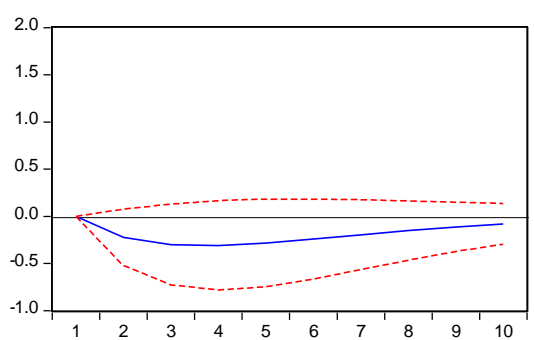

Response of ISCTRROICC to ISCTRWACCC(-1)

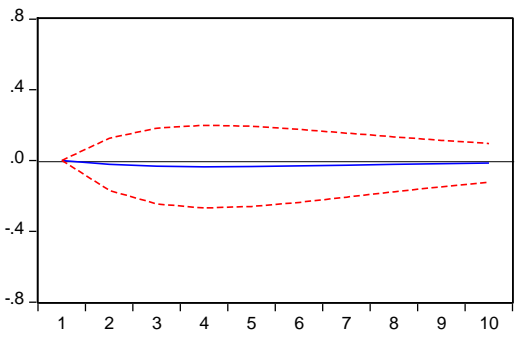

SKB has also regressed with PE, ROE, ROIC and WACC but first lag for the WACC variable in the VAR model was used by considering that it would affect the model with one period delay. The lag length for this VAR models is determined as one with using information criteria. The effect of WACCEVA on this system is also tested and found insignificant.

\section{Figure 3: Response to Cholesky One S.D. Innovations}

Response to Cholesky One S.D. Innovations \pm 2 S.E.

Response of SKBPE to SKBWACC (-1)

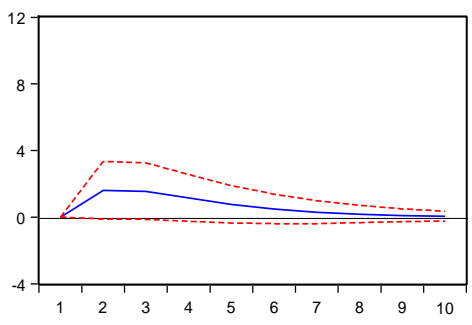

Response of SKBROE to SKBWACC(-1)

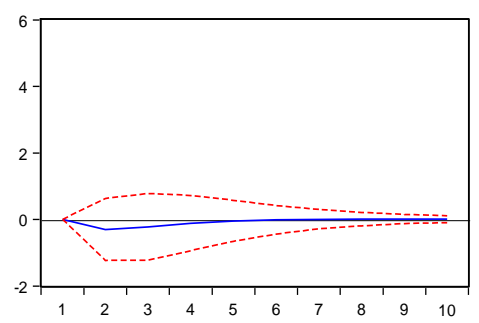

Response of SKBROIC to SKBWACC(-1)

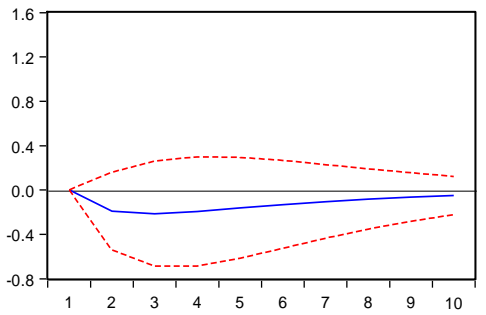


For YKBNK, one lagged VAR model is applied using lag length of LR, FPE, AIC, SC, HQ criterias. WACCEVA is also tested for this stock and the insignificant effect on this system is realized. First lag for the WACC variable in the VAR model was used by considering that it would affect the model with one period delay.

Figure 4: Response to Cholesky One S.D. Innovations

Response to Cholesky One S.D. Innovations \pm 2 S.E.

Response of YKBPE to YKBWACCC $(-1)$

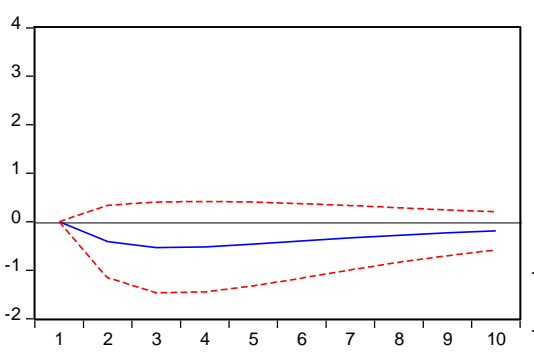

Response of YKBROEC to YKBWACCC(-1)

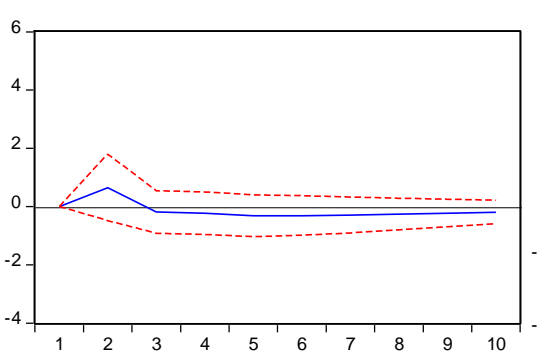

Response of YKBROICC to YKBWACCC (-1)

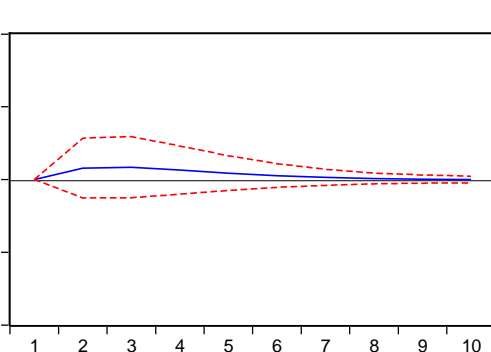

The VAR model estimated for DENIZBANK includes two lagged values of each variable. The effect of WACC on this system rather than WACCEVA has also been tested and found insignificant. First lag for the WACCEVA variable in the VAR model was used by considering that it would affect the model with one period delay. The lag length for VAR models is determined using LR, FPE, AIC, SC, HQ, information criteria. For the VAR system of DENIZBANK, positive shock on WACCEVA leads a negative effect on PE ratio. At the end of the third term, $P / E$ reaches its initial stage and the negative effect fades out. If a shock occurs on WACCEVA, its effect on ROIC has positive impact till the third period and the shock has a negative impact on ROE for seven periods. The VAR model we estimated for QNB stock includes one lagged value of each variable. The effect of WACC on this system rather than WACCEVA has also been tested and found insignificant. First lag for the WACCEVA variable in the VAR model was used by considering that it would affect the model with one period delay. The lag length for VAR models is determined using LR, FPE, AIC, SC, HQ, information criteria.

Figure 5: Response to Cholesky One S.D. Innovations

Response to Cholesky One S.D. Innovations \pm 2 S.E.

Response of QNBPE to QNBWACCEVA(-1)

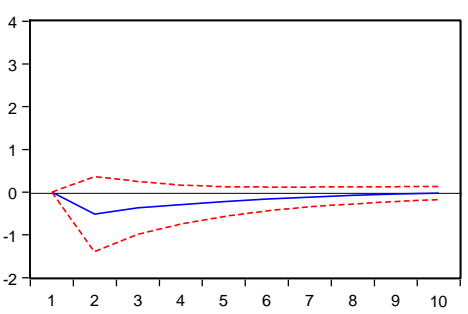

Response of QNBROE to QNBWACCEVA(-1)

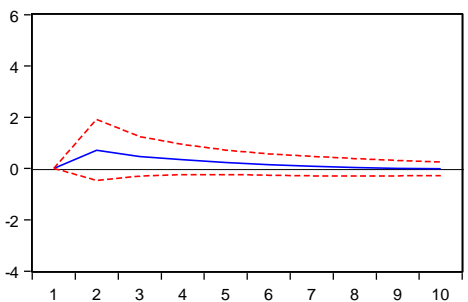

Response of QNBROIC to QNBWACCEVA(-1)

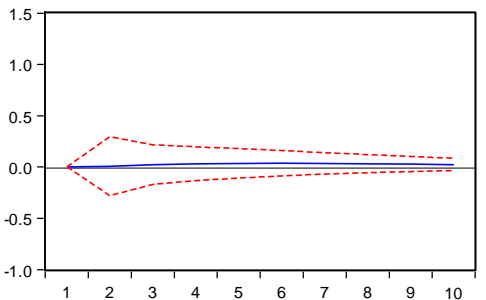

\section{CONCLUSION}

The determinants of stock price are a popular topic in financial literature. Based on previous studies, past evidence state various parameters effect stock price and hence the firm value. Financial leverage as well as the cost of capital is primarily has an effect on the firm value. Furthermore dividends declared, return on equity and return on invested capital are the parameters specifically announced to have effect on the firm stock movement. Furthermore economic value added is another recent tool that investigates the value creation for investors. Some literature indicates significant effect on stock price and some evidence highlights insignificance. Therefore, the literature on the relationship between stock price and selected financial variables such as cost of capital, economic value added, ROE and ROIC indicates different empirical results. In this research Turkish banking industry is selected to test the significance of this relation. In this study we employ specific tests to gather information about the relation between stock price and various financial measures. The database includes Price / Earnings ratio as the stock price proxy. The determinants are modelled as weighted average cost of capital (WACC), Economic value added (EVA), Return on equity (ROE) and Return on Invested Capital (ROIC). The quarterly data consist of the time period between 2006Q1-2018Q3. Augmented Dickey Fuller (ADF), Phillips - Perron (PP) unit root tests are employed furthermore VAR models are applied to test the relation. The summarized results indicate that economic value added has significant effect on firm value for DENIZ and QNB stocks. WACC and EVA variables have one period lagged effect for all stocks. 


\section{REFERENCES}

Abhyankar, A., Ho, K. Y. and Zhao, H. (2005). Long-run post-merger stock performance of UK acquiring firms: a stochastic dominance perspective, Applied Financial Economics, 15, 679-90.

Alonso, P. A., Iturriaga, F. J. L. and Sanz, J. A. R. (2005). Financial decisions and growth opportunities: a Spanish firm's panel data analysis, Applied Financial Economics, 15, 391-407.

Atchyuthan N. and R. Vijayakumaran (2017). The determinants of price earnings ratio: Evidence from Sri Lankan Listed Manufacturing companies Conference: Conference: Twenty-Fourth Annual Sessions of Jaffna Science Association, At Jaffna Sri Lanka, Volume: 24

Becchetti, L. and Adriani, F. (2004). Do high-tech stock prices revert to their 'fundamental' value?, Applied Financial Economics, 14, 461-76

Brio, E. D., Miguel, A. D. and Pindado, J. (2003). Investment and firm value: an analysis using panel data, Applied Financial Economics, 13, 893-903.

Firth, M. (1998). IPO profit forecasts and their role in signalling firm value and explaining post-listing returns, Applied Financial Economics, 8, 29-39.

Jones, E. and Danbolt, J. (2004). Joint venture investments and the market value of the firm, Applied Financial Economics, 14, $1325-31$.

Keasey, K. and Short, H. (1997). Equity retention and initial public offerings: the influence of signalling and entrenchment effects, Applied Financial Economics, 7, 75-85.

Naceur, S. B. and Goaied, M. (2002). The relationship between dividend policy, financial structure, profitability and firm value, Applied Financial Economics, 12, 843-49.

Naceur, S. B. and Goaied, M. (2004). The value relevance of accounting and financial information: panel data evidence, Applied Financial Economics, 14, 1219-24.

Poker J. H., V. M. Murakami and M. M. Belli (2015). Relation between EVA and Capital Structure in the Worldwide Steel Mill Industry in Economic Crises: A Study from 2006 to 2011. International Proceedings of Economics Development and Research IPEDR vol.85 (2015), IACSIT Press, Singapore.

Ramcharran H. (2002). An Empirical Analysis of the Determiants of P/E ratio in emerging markets. Emerging Markets Review, Volume 3, Issue 2. 